\title{
Genéza prvého významu slova rasa: od koní k ludiom
}

\author{
Milan Hrabovský
}

DOI: 10.21104/CL.2021.1.05

The Origin of the First Meaning of the Term "Race": from Horses to Humans

\begin{abstract}
The study focuses on the etymology and origin of the meaning of the term "race", which was first used with a reference to a herd of horses with excellent (riding) characteristics and went on define human groups. Researchers examining the etymology of the word race have come up with three established hypotheses as to its origin: the "Arabic", "Greek-Latin" and "French" hypotheses. Here, the focus is on the French hypothesis, since if the French hypothesis is applied, then the word "race" comes from the French haras, meaning "herd" (of horses) with "aristocratic", "noble blood origin". The original meaning of the term race referred to the quality of "blood" ("origin") of a unique "herd" of horses or dogs. The term gradually began to be used for a "quality family" (caste) from a socially "noble" group of people (knights, bishops or king), who spoke of themselves in terms of aristocratic, noble, family origin, thus in the sense of a noble "bloodline".
\end{abstract}

\section{Key words}

race, genealogy, haras, linage, origin, etymology, racism

\section{Contact}

Mgr. Milan Hrabovský, PhD., Bratislava Policy Institute, Klariská 328/14, 81103 Bratislava, Slovak Republic; e-mail: hrabovsky@bpi.sk

\section{Jak citovat / How to cite}

Hrabovský, Milan. 2021. Genéza prvého významu slova rasa: od koní k luud'om. Český lid 108, 83-101. https://doi.org/10.21104/CL.2021.1.05 


\section{Úvod}

Claude-Olivier Doron upozornil, že pri skúmaní etymológie a významu slova rasa je dôležité zacielit výskum na tzv. histoire épistémologique, na výskum rozličných historických významov slova rasa (Doron 2018), pretože väčšina štúdií a analýz týkajúca sa pojmu rasa sa venuje skúmaniu tohto pojmu, aby pomocou neho objasnili (či sa pokúsili vysvetlit') vznik rasizmu (Hrabovský 2018). Podla Dorona je nevyhnutné rozlišovat' medzi (1) skúmaním epistemologickej histórie konkrétneho významu slova rasa, ktorý viedol k rasizmu, pričom význam slova rasa využitý v rasizme je iba jeden $\mathrm{z}$ množstva významov tohto slova; (2) skúmaním epistemologickej histórie odlišných významov slova rasa, ktoré sa objavili v histórii západnej civilizácie (Doron 2018: 479). Predkladaná štúdia sa zameria na bod (2), na etymológiu a vznik významu slova rasa, ktorý sa z jeho prvotného použitia na stádo koní s excelentnými (jazdnými) vlastnostami využil na definovanie ludských skupín.

\section{Tri hypotézy}

Etymologický výskum preukázal, že počas obdobia rokov 1200 až 1500 (Conze a Sommer 1994: 137; Hannaford 1996: 5) sa slovo rasa začleňuje do viacerých európskych jazykov. Slovo rasa sa objavuje v angličtine (race), francúzštine (raza, raca), v kastílskom jazyku (raza), portugalčine (raça), španielčine ( $r a z a)$, taliančine (razza, raza), nemčine (reitza, reizza, rasse) (Banton 2004: 333-334; Budil 2005: 1-167; Barnshaw 2008: 1091-1092; Smedley a Smedley 2012: 35-36). Medzi odborníkmi nepanuje zhoda, z ktorej jazykovej oblasti sa slovo rasa kreovalo (Voegelin 1998: 80; Smedley a Smedley 2012: 36). Napriek tomu odborný výskum, skúmajúci etymológiu slova rasa, dospel k viac-menej trom ustáleným hypotézam: k „arabskej“, „grécko-latinskej“ a „francúzskej“ hypotéze. Podla Voegelina vystopovat', aká hypotéza platí pri pôvode slova rasa, sa nám už asi nepodarí, čo však minimálne dokázatel’né je, že slovo rasa pochádza z regiónu južnej Európy (1998: 82).

\section{Arabská hypotéza}

Slovo rasa môže pochádzat' z arabského termínu ra's, rás (hlava, hlava dobytka, začiatok, pôvod) a príchod Arabov na Pyrenejský polostrov mohol vniest' $r a$ 's, rás do španielčiny. Táto hypotéza uvádza, že slovo rasa sa dostáva $\mathrm{z}$ arabského $\mathrm{ra}$ 's, rás do španielskeho raza; z toho jazyka preniká do talianskeho razza a francúzskeho race, a následne do nemeckého rasse (Klein 1966: 1294; Burleigh a Wipermann 1991: 24; Stewart 1992: 365-366; Conze a Sommer 1994: 140; Hannaford 1996: 5; Smedley a Smedley 2012: 36). 


\section{Grécko-latinská hypotéza}

Slovo rasa môže pochádzat' z 15. storočia z latinského ratio (poriadok, systém, rozum, v akuzatívnej forme ako druh, trieda, rod, typ, rodina) alebo z gréckeho a neskôr latinského radix (vetva, koreň alebo generácia, pokolenie) (Valpy 1828: 392; Liddell a Scott 1901: 1355; Klein 1966: 1294; Chiarelli 1991: 7; Memmi 1992: 12; Smedley a Smedley 2012: 36; Budil 2013: 31-32). Slovo radix uvádza aj L'Encyclopédie (1751-1772) (Diderot a D’Alembert 1779: 202). Táto hypotéza odmieta arabský pôvod a tvrdí, že slovo rasa pochádza z latinského radix alebo ratio (Hiter 1822: 1038; Conze $a$ Sommer 1994: 139; Liberman 2009).

\section{Francúzska hypotéza}

Haras

V roku 1959 objavil Gianfranco Contini, že talianske razza je prekladom pôvodného francúzskeho slova "haras“, avšak slovo "haras“" sa neobjavilo v odborných knihách, ale v slovníku chovatelov a nebolo používané na ludí (Doron 2016: 44). Contini rovnako poukázal, že napríklad Dante používal slovo razza vždy len na zvieratá (Liberman 2009). Continiho objav potvrdil Charles de Miramon, ktorý zistil, že v jednom z prvých súhrnných francúzskych slovníkov od Jeana Nicota Thresor de la langue française (1606) sa rasou označovali konkrétne „typy“ koní a loveckých psov:

„Rasa [Race], vytvorená z genitívu latinského radix, cez synkopu strednej slabiky, znamená pôvod. Takto sa hovorí o l'ud'och, koňoch, psoch a iných zvieratách, že sú z dobrej alebo zlej rasy [...] A že rasa španielskych koní alebo rasa francúzskych loveckých psov pochádza z atd'. Za rasu sa tiež pokladajú šlachta, sorta, druh. Du Fouilloux v jeho Venerie vysvetluje, že Trójania bežne lovili v ich lesoch s takouto rasou psov, ktoré ked' objavili jeleňa, nepolavili v prenasledovaní, kým nebol mŕtvy; to znamená s takou šlachtou, sortou a druhom psov atd" "(Nicot 1606; Miramon 2013: 200)

Jean Nicot ponúka vzácnu citáciu z francúzskej encyklopédie loveckých psov Venery (1561), ktorá sa zaoberala rozličnými „rasami“ psov. Najstaršie použitie slova rasa na loveckých psov sa objavuje v básni od Jacquesa de Brézé s príznačným názvom La chasse (Lov), v ktorej ospevuje polovačku (okolo roku 1481) na vysokú zver (Brézé 1858: 21; Miramon 2013: 201).

Jacques de Brézé využil vo svojej básni význam slova rasa, ktoré sa do francúzskeho jazyka dostáva prostredníctvom stredovekého kompendia 
rímskej histórie Li Fet des Romains (Faits des Romains), spísaného približne medzi rokmi 1211-1223 (Vogel 1932: 213-214). Vo Faits des Romains sa objavuje popis Caesarovho koňa, ktorému sú pripísané excelentné vlastnosti, nakol'ko pochádzal z „haras“ (Miramon 2013: 202). Faits des Romains bolo neskôr (v 13., 14. a 15. storočí) preložené do talianskeho I fatti di Cesare a slovo haras sa mení na raza (Banchi 1863: 276; Miramon 2013: 202). V roku 1934 objavil Louis-Fernand Flutre aj portugalský preklad Vida y hechos de Cayo fulio Cesar z 15. storočia (Flutre 1934: 88). Haras označoval súhrnný názov pre vyberané stádo, čriedu chovných koní a v tomto význame sa dostáva do francúzštiny (ako žrebčín, žrebčinec) (Flutre 1934: 202). O koňoch priamo hovorí aj jeden z významov slova rasa v L’Encyclopédie (1751-1772):

„[pri rase] sa hovorí o konkrétnych druhoch niektorých zvierat, hlavne koní [...] Ak chcete vytvorit' rasu, je potrebné si vybrat' dobré kobyly. Kôn výbornej rasy je ten, ktorý pochádza z cudzieho koňa, známeho jeho znamenitostou. "(Diderot a D’Alembert 1779: 202)

Stádo, kde sa rodili kone s lepšími (požadovanými) vlastnostami než v inom, bolo opisované aj ako „stádo“ s „aristokratickým“, „vznešeným“, „ušlachtilým" pôvodom.

Na konci 15. storočia bol objavený extrakt z antických prác Pro nobilitate od neznámeho autora, ktorý obsahoval autentický fragment Plutarcha. Plutarchos v tomto fragmente prepojil vznešenú ušlachtilú krv [le sang noble] s ušlachtilostou [noblesse] istých typov koní, psov, vín a olivových stromov, pričom tvrdil, že táto ušlachtilost' by mohla byt' prenášaná cez semeno [semence]. V tomto fragmente Plutarchos významovo spojil „ušlachtilú dedičnú krv"s kvalitnou rasou [race] koní a psov (Miramon 2008: 157-210).

Avšak v roku 1891 publikoval Jean-Jacques Salverda de Grave stredoveký francúzsky básnický román Roman d'Énéas (Enéas), ospevujúci príbeh Aeneasa (Eneas) po jeho úniku zo zničenej Tróje, ktorý bol napísaný okolo roku 1160 , teda asi 60 rokov pred Faits des Romains. Vo verši 3937 sa objavuje slovo haraz, vo význame „stádo koní“ (Salverda de Grave 1983-1985: 3935-3937). ${ }^{1}$ Takže niekde medzi rokmi 1160-1223 už malo slovo haras/haraz význam „nádherného“ („kvalitného“) stáda

1 „poutrels orent de Capadoce, qui n'ont mehaig, jale ne boce, d'un marveillos haraz de mer, et molt sont legier a armer“ [„žriebätá z Kapadócie, ktoré nemajú omrzliny, kostné tumory, ani hrb, nádherné morské haraz („stáda“), a vel'mi rýchlo skrotitel'né"] 
koní. Ten význam slova haras sa využíval aj približne o 500 rokov neskôr, napríklad v jednom z Ordonnance de Roy (Nariadení Král'a) z 15. júna 1751, v ktorom král' Ludovít XV.

„[...] podla nariadenia z 31. augusta 1718 , vysvetlil jeho zámer ohl'adom služby žrebčínov [Haras], pokial'ide o regióny Roussillon, Conflans, Cerdagne a Foix: Jeho Veličenstvo bolo informované, že je možné dodat' najvýnosnejšie typy z týchto žrebčínov [haras] pre úspech v produkcii najlepších druhov koní [...]"(Ordonnance 1751:1-2).

\section{Lignée, lignage}

Približne v roku 1160 sa stretávame pravdepodobne s prvým (zaznamenaným) použitím slova rasa („haraz“), a to vo význame nádherného, najlepšieho stáda koní, pričom v tomto období (dosial') nebola objavená žiadna zmienka o použití slova „haraz" na ludí. V 13., 14. a 15. storočí sa slovo rasa využíva na popis vznešeného, kvalitného stáda koní. Slovo rasa však nebolo synonymum slov „stádo“ či „črieda“, ale skôr synonymum pôvodu (genealógie) „stáda so vznešenou, ušlachtilou krvou“, slovo rasa popisovalo „stádo“, kde sa nachádzajú excelentné kone, pretože pochádzajú zo vznešenej, ušlachtilej krvi. Tomuto nádhernému, najlepšiemu stádu (koní) sa pripisovala „vznešená krv“ [le sang noble], a to z dôvodu, že „krv“" [sanguis] sa už v antickom Ríme považovala za "nosič“ vznešeného pôvodu či vznešenej rodovej línie (Miramon 2013: 208-209, 212). Prvotné použitie slova rasa teda neznamenalo "skupinu“, ale "une entité généalogique" (genealogickú entitu) (Doron 2016: 9).

Pre zodpovedanie otázky, ako bolo možné, že sa slovo rasa „prenieslo“ zo zvierat (koní a psov) na ludí, je dôležité ozrejmit' stredoveký kontext, v ktorom sa začína hovorit' o význame „pokrvnej rodovej línie“ [lignage, lineage] niektorých sociálnych skupín.

Až do 19. storočia - kedy sa objavuje Darwinova teória - definovali rôzne sociálne skupiny v Európe svoj pôvod (genealógiu) pod vplyvom Biblie, odkazom na jedného zo synov biblického Noeho: Jefet, Chám a Šém. Na tomto rozdelení postavil stredovek svoje chápanie sociálnych skupín: Jefet ako predchodca nobility, šlachty, aristokracie, Šém ako predchodca kňazov (neskôr semiti) a Chám ako predchodca nevolníkov, otrokov (Braude 1997: 103-104). Podobne aj neskoršie rané nacionalistické reflexie rodiacich sa národov legitimizovali svoj „rodokmeň“, odvolávaním sa na pôvod z jedného z týchto synov Noeho (Poliakov 1996: 7; Hoquet 2013: 1473). Ako píše Ivo T. Budil: 
„Rozsiahle sofistikované genealogické stromy inšpirované antickými predlohami a čerpajúce zo starovekých a biblických legiend sa stali súčastou západnej intelektuálnej tvorivosti až do devätnásteho storočia." (Budil 2013: 222)

Tento význam slova rasa (pôvod, genealógia) čerpal svoju autoritu z dejín - až do času mýtu -, pretože „kopanie“ v minulosti viedlo - v závislosti na interpretačnom kontexte (Biblia, Trója, Rím, Germáni, Kelti, Árijci, predok, jazyk, krv, pôda) - k „objavu“ prapôvodného „bodu nula“, ktorý „založil“" danú sociálnu kastu, klan, spoločenstvo a nakoniec národ. David Chao Castro a Marta Cendon Fernández upozorňujú, že

„[...] mýtický naratív, tak ako biblický naratív, umožñuje znovu sa vrátit' $k$ slávnej minulosti národov a monarchií, a teda prináša nevyhnutnú záruku pre prežitie tejto vel'koleposti až do okamihu spisania tohto naratívu. Vzájomne previazané v histórii (viac vymyslené ako skutočné), mytológii a Biblii takto ponúkli svedectvá a predkov potrebných pre potvrdenie líniú, královských, ako aj šlachtických, a umožnili privilegovat' pôvod a prestiž dynastie." (Castro a Fernández 2018: 195)

Naratív „vznešenej pokrvnej rodovej línie“ [lignage, lineage], ktorý využíval metafory „modrej krvi“, „,aristokracie“, „nobility“ „vznešenosti“, „ušlachtilosti“, či až „dobrého mena“ (Diderot a D’Alembert: 1779: 202), sa rozvinul počas stredoveku a využíval mýty (grécka a latinská mytológia) a niektoré biblické pasáže, ale aj reálne historické udalosti, aby nimi potvrdil, že nárok na kral'ovanie vychádza z „královskej línie“. Túto „metódu“ využívali v stredoveku rôzne „král'ovské" dynastie v Európe (Castro a Fernández 2018: 195-196). Existujú aj hypotézy, že germánske slovo král [könig] pochádza z indogermánskeho gen (narodit' sa): král je osoba, ktorá sa „dobre narodila“, „má dobrý pôvod“, pochádza zo „slávnej rodiny“, takže právo vládnut' bolo „vpísané" v „rodokmeni“ [généalogie] „král'a“ (Dumezil 2015: 42). Následne sa tento vybájený mýticko-biblický naratív „vznešenej pokrvnej rodovej línie“ stával súčastou oficiálnych „historických“ kroník, a navyše, kedže tento „vznešený pôvod“ údajne potvrdzovala aj Biblia, královská línia [lignage royal] bola považovaná za „Bohom posvätenú“ (Castro a Fernández 2018: 196). Dôležité v tejto súvislosti bolo aj chápanie rodiny v 11. a 13. storočí, s poznámkou, že samotné slovo „rodina“ [familia] nebolo v tomto období vôbec používané. Chápanie rodiny v tomto období vychádzalo z konceptu príbuzenstva, príbuznosti, spojeného cez „pokrvnú rodovú líniu“ a popisovalo skôr vzt'ahy než uzavreté skupiny. Táto „po- 
krvná rodová línia“ bola prekladaná latinským slovom genus (rod), ktoré vyjadrovalo, že daná žena alebo muž má vznešený, ušlachtilý či vynikajúci, slávny pôvod (Ariès a Duby 1988: 85-119). „Rodinné“ línie boli „identifikovatelnéc cez rodové meno, predávané z generácie na generáciu, a cez cnost' predkov (virtus), ktorá prúdila „v krvi“ (Ariès a Duby 1988: 85-119). Dominique Barthélemy uvádza príklad tohto prepojenia „krvi“ a „rodovej línie" [lignage, lineage]:

„Keby si nejaký muž zobral ženu z vyššej vrstvy, krv jeho rodovej línie [lineage] mohla byt'zavlažená krvou králov, princov a grófov. Tento pravidelný prílev dobrej krvi nielen omladzoval rodinnú ušlachtilost', ale zabezpečoval aj súdržnost' dominantnej triedy. ,Dobré manželstvá boli starostlivo zaznamenané v domácich rodokmeňoch. " (in Ariès a Duby 1988: 120)

$\mathrm{Na}$ tento význam slova rasa (prepojenie „pôvodu“, „krvi“ a „rodovej línie") poukázala aj historička Arlette Jouanna, autorka rozsiahlej trojzväzkovej doktorskej práce L'idée de race en France au XVI eiècle et au début du XVIIe siècle (Idea rasy vo Francúzsku v 16. a na začiatku 17. storočia). Arlette Jouanna zdôraznila, že slovo rasa nemalo vo svojich začiatkoch etnický význam, ale význam pôvodu, rodokmeňa, línie, potomstva [lignée] (Jouanna 1975: 17). A práve tento význam slova rasa („vznešeného (po) krvného pôvodu“) začal byt' používaný na stredoveké sociálne skupiny rytierov, lordov, barónov, až králov - teda sa obohatil významom morálnej a sociálnej ušlachtilosti (Miramon 2008: 157-210) - a mal tak vyjadrit' ich sociálnu dominanciu nad skupinami bez tohto vznešeného „(po)krvného“ („rasového“) pôvodu (Jouanna 1975: 17).

V 16. a 17. storočí sa tento význam „vznešenej krvnej/rodovej línie“ stáva súčastou významu pojmov ako domus, familia, gentilitas, genus, propago, sanguis, soboles, stirps, progenies, až do významu, pomocou ktorého bolo možné na začiatku 19. storočia povedat' „il vient d'une noble

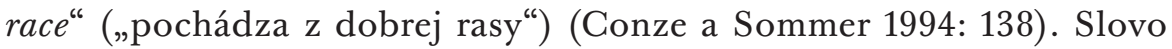
rasa plnilo funkciu identifikácie sa s „kvalitným chovom“ či s „dedičnou krvou“. Prioritným kritériom zaradenia (sa) do príslušnej rasy teda nebol fyzický výzor, ale „príbuzenstvo“ („populácia“, „potomstvo“) majúce „kvalitný“, „vznešený“ alebo „nekvalitný“, „nevznešený“ rodokmeň (pôvod) (Banton 1979: 16-17).

Ak platí táto francúzska hypotéza - a pramene poukazujú na to, že táto hypotéza je obhájitelná -, potom slovo rasa pochádza z francúzskeho haras, vo význame „stáda“ (koní) s „aristokratickým“, „vznešeným“, „ušlachtilým“" (po)krvným pôvodom. Navyše, tento význam slova rasa (vznešeného pôvodu, vznešenej krvi) umožnil začlenit' rasu do „prírody“ („biológie“), 
pretože „Vznešená krv“ (rasa) sa prenášala z nejakých predkov na potomkov prostredníctvom plodenia (Tournier 1992: 105-107). Tak Antoine Furetière uvádza v roku 1690 v jeho Dictionnaire, že rasa je: „Potomstvo [Lignée], generácia pokračujúca z otca k synovi: hovorí sa tak o predkoch a potomkoch" (Teysseire 1992: 43).

Prvotný význam slova rasa nepopisoval fyzický výzor (sfarbenie kožného pigmentu, tvar lebky, farbu očí), ale pôvod, líniu, potomstvo alebo rodokmeň. Tento význam slova rasa vychádzal z myšlienky dlhej línie predkov, kde sa prenášala „vynikajúca kvalita“, ktorá ale nemusela nevyhnutne súvisiet' s fyzickými (somatickými) vlastnostami (Conze a Sommer 1994: 138). Rasa označovala isté „výnimočné kvality“ [qualités nobles], či „stav ušlachtilosti" [l'ordre de noblesse], ktoré sa počas 16. a 17. storočia začali považovat' za „zdedené", teda sociálne nerovnosti za začali považovat' za nerovnosti „od prírody“ [l'ordre naturel] (Jouanna 1975: 17).

Colette Guillaumin ponúka zhrnutie posunov týchto významov slova rasa: (1) rasa bola spočiatku aplikovaná len na „vznešené rodiny“, na „ušlachtilé, aristokratické" rody a (2) bola „temporálnou“ kategóriou; rasa sa týkala pôvodu, genealógie, histórie a vyjadrovala tak „legálny“ status v spoločnosti; postupne sa ale rasa (2) začína používat na popis sociálnych skupín a stáva sa (3) „genetickou“ („hereditárnou“) kategóriou (Guillaumin 1972: 247).

\section{Prenikanie slova rasa do európskych jazykov}

Aj ked' sú informácie o prenikaní slova rasa do európskych jazykov len kusé a približné, predsa len môžeme povedat', že najranejší význam slova rasa sa využíval vo význame pôvodu „dobrej krvi“, rodokmeňa, potomstva či „rodiny“. Prvotný význam slova rasa sa týkal pôvodu istého rodu/chovu/ stáda koní (či psov), ktoré boli šlachtené pre ich vznešený pôvod („krv“) (Conze a Sommer 1994: 139).

\section{Anglický jazyk}

Michael Banton uvádza, že rasa, vo význame „ludskej skupiny“, sa prvýkrát objavuje v anglickom jazyku v básni Williama Dunbara The Dance of the Sevin Deidly Synnis (1508) vo verši „,backbyttaris of sindry racis“ („,nactiutŕhači“ rôznych rás) (Banton 1998: 17; Banton 2010: 129), ktorý bol skôr volným popisom skupiny, podobne ako odkazoval John Bunyan v jeho Pútnikovej ceste na „rasu svätých“ (Smedley a Smedley 2012: 36). Ashley Montagu kladie dátum objavenia sa slova rasa v angličtine do neskoršieho obdobia: prvé použitie rasy v angličtine vo význame "pôvodu“ (rodokmeňa), pod- 
la neho zaviedol John Foxe v The Book of Martyrs (1570) v zmienke o "the outward race \& stock of Abraham" (vonkajšia rasa \& pôvod/rod Abraháma) (Montagu 1965: 18).

\section{Španielsky jazyk}

Pokial' ide o španielsky jazyk, jeden z prvých španielskych slovníkov Tesoro de la lengua castellana o española (1611) spájal rasu (raza) na jednej strane s „kastou alebo kvalitou pravých koní”, no na druhej strane odkazoval aj na ludí, hlavne v negatívnom význame, pretože rasou sa označoval maurský alebo židovský „pôvod“. Od roku 1391 prebiehali v Španielsku násilné konverzie židov, a týchto nových krestanov podozrievali, že konvertovali len „naoko“. Títo noví krest́ania, označení pejoratívnym slovom marranos („svine“), sa úspešne integrovali do spoločnosti, kde obsadili miesta $\mathrm{v}$ administratíve, armáde či na univerzitách. $\mathrm{Z}$ dôvodu pochybnosti o ich „čistote viery“ vydáva pápež Sixtus IV. v roku 1478 bulu Exigit sincarea devotionis, ktorá umožnila založenie inkvizície, spadajúcej priamo pod španielske král'ovstvo. Následne vrchný španielsky inkvizítor Torquemada použil „nástroj“ na zistenie „pravých krestanov“, a to cez určovanie ich "čistej krvi“ [limpieza de sangre], čo inými slovami znamenalo určovanie ich pôvodu (rodokmeňa, genealógie). Každý kandidát na verejnú funkciu musel preukázat' „čistotu“ svojej „krvi“ (svoj „pôvod“) spätne do šiestej generácie. Dôraz na „čistotu krvi“ znamenal, že práve v krvi (v „rodokmeni“, v „pôvode“, v „biológii““ človeka) sa nachádza „skutočná“ povaha, sklony a charakter. Inkvizícia využila "genealogickú metódu“ limpieza de sangre, kde zistovanie podla "fyzického výzoru" nezohrávalo významnejšiu rolu² (Fredrickson 2002: 32-36, 124; Szabó 2004: 249; Martínez 2008; Budil 2013: 265-266; Courtine-Denamy 2013: 1009-1011).

Kastílske slovo „raza“ sa najprv používalo na označenie choroby kopýt u koní, ale medzi chovatel'mi sa presadilo vo význame rodokmeňa, pôvodu. David Nirenberg cituje populárny manuál pre chov koní, napísaný v roku 1430, ktorý radil, že „[...] ten, kto chce mat' dobrú rasu a kastu [bona raça o casta] koní, hladá predovšetkým koňa alebo žrebca, ktorýje dobrý a krásny, a s dobrou srstou a kobylu, ktorá je vel'ká a dobre stavaná, a s dobrou srstou" (2013: 248-249). Prenos „rasy“ ako synonyma „dobrého pôvodu“ („dobrej krvi“) kvalitného stáda koní na l'udí, umožňoval hovorit' aj o lud’och ako o „stáde“ či „chove“ s nejakým daným (po)krvným pôvodom (Smedley a Smedley 2012: 37-38). Básnik Alfonso Martínez de Toledo napísal v roku 1438:

2 Podobne aj rasistické zákony na americkom Juhu legislatívne zaviedli pravidlo „jednej kvapky krvi“ [one drop rule], ktoré malo určit' „neviditel'nú čiernost". 
„[...] dobrý muž dobrej rasy [bueno e de buena raça] sa vždy vracia kjeho pôvodu, kým mizerný muž, zlej rasy a zlého rodokmeňa [de vil raça e linaje], bez ohladu na to, aký je mocný a bohatý, sa vždy vracia do hanebnosti, z ktorej pochádza"(Nirenberg 2013: 249-250).

David Nirenberg uzatvára:

„V krátkosti, slová ako raza, casta a linaje (a ich variácie v rôznych iberských románskych jazykoch) boli už usadené v identifikovatelných biologických predstavách spojených so šlachtením a reprodukciou zvierat v prvej polovici pätnásteho storočia. Navyše, náhla a explicitná aplikácia tohto slovníka na židov sa chronologicky (1430) prekrývala s vynorením sa anti-converso ideológiou (už prítomná na príklade Alfonsa Martínez de Toledo), ktorá hladala nové religiózne a diskriminačné kategórie a legitimizovala tieto kategórie ich naturalizovanim." (2013: 252)

\section{Nemecký jazyk}

Voegelin uvádza, že tento význam slova rasa (pôvod, genealógia) sa dostáva do nemeckého jazyka z francúzskeho jazyka (Voegelin 1998: 84). Naopak Brunetto Chiarelli obhajoval grécko-latinskú hypotézu, pretože talianske razza sa podl'a neho objavilo skôr než španielske raza, a to okolo roku 1400 v básni Intelligenzia od, asi, Dina Compagniho. Brunetto Chiarelli datuje objavenie sa slova rasa v taliančine do 14. storočia, ktoré v tomto období označovalo dlhú líniu [linea] predkov a potomkov, najprv používanú na zvieratá. Význam slova raza odkazoval na pokrvnú líniu v zmysle latinského linea sanquinis, teda pokrvného rodu či pôvodu (Chiarelli 1991: 7).

Cestou, ktorou sa dostávajú významy slova rasa ako „pôvodu“, „reprodukcie“ či „rodovej línie“ už priamo cez slovo rasa do nemeckého jazyka, bol preklad latinského vydania knihy De generis humani varietate nativa (O vrodenej rozmanitosti ludského rodu, 1775) od Johanna Friedricha Blumenbacha. V tretom vydaní z roku 1795 sa dva latinské termíny varietas a gens preložili nemeckým race. Kým v latinskom vydaní varietas odkazovala na „poddruh“ a gens na „rodové“ chápanie „ludu“, tak v nemeckom vydaní sa napríklad veta „varietates coloris gentilitiae“ preložila ako „druhy farebných rás" alebo veta "facies gentilitia“ ako „rasové tváre“" (Voegelin 1998: 86). Blumenbach, v nemeckom vydaní, delí ludský druh (Homo sapiens) do „podskupín“, ktoré už neoznačuje pojmom varietas, ale pojmom racen. Prečo táto zmena? Blumenbach sa explicitne odvoláva na Immanuela Kanta a jeho rasovú kategorizáciu: „Navyše, neviem, prečo noví naturalisti opisujúci 
ludstvo, nepoužívajú stanovené definície od nášho vel'kého Kanta. Pochybujem, že by sme mohli nájst' lepšie. "(Blumenbach 1789: 259)

Nemecký slovník bratov Grimmovcov z roku 1893, podobne ako Voegelin, tvrdí, že slovo rasa [Rasse] sa dostáva do nemeckého jazyka z francúzskeho race. Slovo rasa definuje tento slovník ako „spoločný kmeň“:

\begin{abstract}
„Medzi dedičnými odlišnostami zvierat, ktoré patria k jednému kmeňu, sa nazývajú rasami tie, ktoré si [...] pri každej reprodukcii v dlhých rodových líniách zachovajú znaky [...]. Pojem rasy zhŕna v proom rade pojem spoločného kmeňa [eines gemeinschaftlichen stammes], v druhom rade nevyhnutne dedičné vlastnosti klasických rozdielov medzi potomstvom." (Grimm a Grimm 1893)
\end{abstract}

\title{
Slovenský jazyk
}

Slovo rasa nie je pôvodné české alebo slovenské slovo, ale do týchto jazykov preniklo z iných jazykov. Kým české etymologické slovníky uvádzajú, že slovo rasa vchádza do češtiny z nemeckého rasse, poprípade francúzskeho race (Machek 1957: 509; Rejzek 2001: 528), slovenský etymologický slovník uvádza, že slovo rasa preberá slovenčina z francúzskeho race, ktoré vychádza z talianskeho razza (Králik 2016: 492).

Český aj slovenský jazyk prijal slovo rasa, a pokial' ide o jeho význam, Anton Bernolák definoval slovo "raca" v jeho diele Slowár Slowenskí ČeškoLatinsko-`̌Nemecko-Uherskí z roku 1825 ako „plemeno“ a slovo „plemeno“ ako „fetus, fetura, Frucht, fajt, fata“, pričom pri slove „plemeno“ udáva význam „caninum genus, Hundswuth“ (Bernolák 1825: IV.2683, III.2027), č́m, pravdepodobne, stotožňoval „raca“ a „plemeno" so zvieratami, hlavne psami, ale ešte nie s l'ud'mi. O dvanást' rokov neskôr, v roku 1837, vydáva Pavol Jozef Šafárik Slowanské starožitnosti, kde slovo „plemená“ už priamo používa na označenie l'udských skupín. Pavol Jozef Šafárik pri jeho delení „plemien“ využil slovo „plémě“ ako synonymum slova rasa a tento krok odôvodnil odkazom na zahraničnú literatúru o rase, s ktorou bol evidentne dobre oboznámený (Šafařík 1869: 25). Možná hypotéza, prečo Pavol Jozef Šafárik použil slovo rasa na ludí, je, že išlo o sčítaného intelektuála, ktorý sledoval vedeckú literatúru jeho čias a táto vedecká literatúra začala používat slovo rasa na ludí. Šafárik sa pýta, ako sa rozšírilo celé ludské pokolenie na rozličné „plemená“ [plemena], „kmene“ a „národy“. Pri odpovedaní na túto otázku by sme mali zobrat do úvahy tri hlavné stránky: prírodnú (skúma „postavu ludskú a zloženie telesné"), jazykovú (skúma ,jazyky, reči a nárečia, ktorýmiž se ludstvo od seba delí") a dejinnú (skúma „premeny, ktoré národové v obcovaní svém společném podnikli“). Pokial' ide o metódu 
prírodnú, jedná sa o „přjrodozpyt“ skúmajúci tie telesné znaky (sú „okom viditel'né"), ktorými sa národy od seba odlišujú. Lenže podla Šafárika sú tieto rozdiely „nespočetné a nepatrné“, takže existuje len málo „čistých národov", ktoré by svoje znaky nepomiešali s inými, a preto sa národy líšia „prírodnými znakmi“ len „nahrubo“. Z tohto dôvodu sa pri rozlišovaní národov musí zohl'adnit' d'alší znak, a to „krv“, „pôvod“ a ,jazyk“. Národy hovoriace „pôvodnými jazykmi príbuznými“ sú vzájomne príbuzné, môžeme preto hovorit', že „takpovediac z jedné krve pošli“. V tomto prípade, v zvláštnej jednote krvi, pôvodu a jazyka, hovorí Šafárik o „príbuznosti kmeňovej“ (Šafařík 1837: 23; Šafař́k 1869: 32).

$\mathrm{Na}$ začiatku 20. storočia sa $\mathrm{v}$ slovenskom jazyku slovo rasa už bežne užívalo na označenie pôvodu l'udí, ako to môžeme vidiet' v diele Kotlín (1901) od Svetozára Hurbana Vajanského: „Gašpar Skladanský pryý raz videl Lejlu a bol očarovaný. ,Princesa!', podumal, žmúriac očami, , a to z drotárskej rasy! Kto by si to pomyslel'. "(Vajanský 1901)

Význam slova rasa vo význame "plemena" či „spoločného kmeňa" prenikol aj do súčasnej slovenčiny. V Slovníkovom portáli fazykovedného ústavu L'. Śtúra SAV nachádzame definíciu pojmu rasa ako „skupinu l'udí s typickými telesnými znakmi“, „biologickú skupinu ludí"; „skupinu ludí“, ktorú slovníky nazývajú aj „sorta“ alebo „plemeno“, vyznačujúce sa istými fyzickými vlastnostami (napr. farbou kože, vlasov, očí, tvarom lebky, stavbou tela a pod.), a taktiež „skupiny ludí" slovníky radia do farebných rás: biela, čierna, žltá rasa (SP JÚLŠS SAV 2020). Slovníky na Slovníkovom portáli fazykovedného ústavu L'. Štúra SAV definujú slovo rasa ako „skupinu ludí s typickými telesnými znakmi, plemeno: biela, čierna, žltá rasa“; „súhrn jedincov s tou istou stálou odchýlkou od druhu“; „súhrn pestovaných jednotlivcov, ktorí v rámci druhu majú spoločné vlastnosti“; „biologická skupina ludí, podmienená historickým vývojom a vyznačujúca sa určitými nepodstatnými fyzickými vlastnostami (napr. farbou kože, vlasov, očí, tvarom lebky, stavbou tela a pod.)“. Podl'a slovníkov sú synonymami slova rasa: druh, odroda, sorta, plemeno, fajta (SP JÚL'Š SAV 2020). Všetky tieto definície spája, že rasu popisujú ako „(biologickú) skupinu l'udí“, ktorá vznikla „historickým vývojom“, ktorá sa vyznačuje istými spoločnými „fyzickými vlastnostami“, predovšetkým farbou pleti. Slovníky implicitne predpokladajú, že rasa je vedecká kategória, ktorú môžeme bez problémov aplikovat' na označenie l'udských skupín. Podobné presvedčenie - že rasa je neproblematická vedecká kategória - sa využíva aj v hesle „rasa“" na slovenskej Wikipédii.

Ak využijeme zdroje v českom jazyku, potom sa môžeme v Antropologickom slovníku prírodovedeckej fakulty Masarykovej univerzity dočítat' o kritickom chápaní pojmu rasa. Rasa popisuje 
„[...] rozdielne somatické vlastnosti používané ku kategorizácii vel'kých skupín ludí; tradičná taxonomická kategória slúžiaca k popisu biologickej rozmanitosti ludských populácii na základe spoločne zdielaných fenotyporých znakov (farby pleti, štruktúry vlasov, rysov tváre a iné). Rasy sa údajne od seba lísia geografickým rozlísením a zdielanými biologickými znakmi, zdedenými po spoločných predkoch. Súčasná molekulárna genetika nepotvrdila existenciu relevantných rozdielov v genóme medzi ludskými populáciami a spochybnila pojem rasy ako striktne oddelenej biologickej kategórie." (Malina 2009)

V tejto definícii, na rozdiel od slovenskej, dochádza k spochybneniu vedeckej validity pojmu rasa ako údajnej biologickej kategórie. A podobne kritická definícia pojmu rasa, na rozdiel od slovenskej Wikipédie, sa nachádza aj pod heslom „lidská rasa“ v českej Wikipédii.

\section{Prenos na ludí}

Či už ide o anglický, španielsky, francúzsky, taliansky alebo nemecký jazyk, medzi odborníkmi panuje vzácna zhoda, že prvotný význam slova rasa odkazoval na kvalitnú „krv“ („pôvod“) špeciálneho „stáda“ koní či psov a postupne sa začal používat' na „kvalitný rod“ (kastu, „rodinu“) sociálne „Vznešenej“ skupiny ludí (rytieri, biskupi či králi), ktorá o sebe hovorila v termínoch aristokratického, ušlachtilého rodu, pôvodu, teda vo význame ušlachtilej „krvnej línie“ (Banton 1979: 17; Conze a Sommer 1994: 137; Hannaford 1996: 5; Budil 2013: 31-32; Stoczkowski 2013: 1479). Tento význam slova rasa sa, pravdepodobne, po prvýkrát objavuje v slovníku hospodárov, pestovatel'ov a chovatel'ov usilujúcich sa vyšlachtit' (vyselektovat') zvieratá s najlepšími vlastnostami (či už pre lov, alebo chovatel'ské účely). Audrey Smedley a Brian D. Smedley uvádzajú, že tento význam slova rasa, zdá sa, „má dlhú históriu v l'udovej kultúre latinského sveta, l'udské pochopenie šlachtenia zvierat sa datuje do ranných agrárnych komunit" (Smedley a Smedley 2012: 37). Môžeme preto uvažovat' aj o hypotéze, že prvotný význam slova rasa sa objavuje ako dôsledok chovatel'ských a šlachtiacich praktík, ktoré odrážali dobové sociálno-kultúrne preferencie hospodárov, pestovatel'ov a chovatelov zvierat (Smedley a Smedley 2012: 37). Následne sa tieto sociálno-kultúrne preferencie, spočiatku primárne aplikované na zvieratá, „odpútali“ od chovatel'ských a šlachtiacich praktík zvierat a použili sa na označenie politicko-sociálnych skupín [politisch-soziale Gruppenbezeichnung] (neskôr nazvaných „lud“, „etnikum“ či „národ“) (Conze a Sommer 1994: 135). Slovo rasa sa objavuje v románskych jazykoch a jeho prvý význam bol spájaný s chovom (stádom) zvierat so špeciálnymi vlastnostami, u ktorých bol dôležitý ich 
pôvod. Postupne sa tento pôvod začal chápat' nielen v pozitívnych, ale aj negatívnych súvislostiach. Pozitívny význam umožňoval vyčlenit' niektoré podskupiny (rýchle/ušlachtilé kone, rýchle/ušlachtilé psy; neskôr aj rytierov či králov) z celej skupiny (kone, psy, ludia). Toto vyčlenenie vychádzalo z „povýšenia“ niektorých vlastností, ktoré dané sociálno-kultúrne prostredie považovalo za „kvalitné“ („rýchlost'“, „dobrý pôvod“, „modrá krv"), a to prostredníctvom presvedčenia, že „kvalita“ týchto vlastností vychádza z kvalitného (po)krvného pôvodu. Negatívny význam naopak umožňoval vyčlenit' niektoré podskupiny pre ich údajne negatívne vlastnosti, vzhl'adom na preferencie daného sociálno-kultúrneho prostredia (Rubiés 2017: 33-81).

Pravdepodobné je, že slovo rasa sa postupne presadilo na definovanie pôvodu „skupiny“ kvalitných koní alebo loveckých psov a po prvýkrát sa použilo na l'udí v 15. storočí. Odkazovalo však na vágne charakteristiky nejakej významnejšej sociálnej skupiny ludí. Spisovatelia v tomto období spájali rasu so vznešeným pôvodom či s istým privilegovaným sociálnym postavením (napríklad „rasa“ biskupov) (Kamín a Machalová 2003: 16; Banton 2004: 333).

Podla inej hypotézy sa slovo rasa použilo na ludské populácie počas 16. storočia v Anglicku (Barnshaw 2008: 1091) a postupne sa rozvíjalo na definovanie „skupiny ludí spoločného zamestnania“ (1500), následne „generácia, pokolenie, kmeň“ (1560), až k „,jednému z najväčších rozdelení ludstva založených na fyzických znakoch“ (1774) (Harper 2001-2020). $\mathrm{V}$ anglickom jazyku sa následne pojem rasa, od 16. storočia, stal dôležitým identifikátorom, ktorý zdôrazňoval nadradenost' anglickej „rasy“ nad germánskou „rasou“, pričom využíval význam „pokrvného príbuzenstva“ (Barnshaw 2008: 1091; Watson 2008: 47-71). Nakoniec, ucelenejšia definícia pojmu rasa sa objavila v šiestom vydaní Slovníka francúzskej Akadémie (1835), kde sa rasou chápalo spoločenstvo ludí žijúcich v tej istej zemi, podobné si fyzickým výzorom (Budil 2005: 41; Isaac 2006: 25). Rasa sa postupne začala chápat' ako skupina ludí, ktorá má spoločný pôvod, navonok identifikovatel'ný prostredníctvom fyzických (telesných) znakov.

\section{„Národy a etniká“"}

Význam slova rasa ako pôvodu (genealógia) sa líšil od spoločnosti k spoločnosti, pretože rôzne sociálne skupiny, neskôr konštituujúce sa ako „národy“ (či „etniká“), medzi sebou viedli spory, ktorá z nich má „ušlachtilejší/vznešenejší pôvod“. Tento význam slova rasa sa v ére nacionalizmu, kedy dochádzalo k vzniku národných štátov, využil pri „stvorení“ zdanlivo homogénnych kolektívov (nazvaných najprv „rasami“ a neskôr „národmi“ 
alebo „etnikami“), pretože umožňoval hovorit' o (údajne) starobylých a dlhodobých jazykových, kultúrnych, či dokonca „pokrvných putách“. Následne, slovami Šloma Sanda, rôzni „konštruktéri minulosti“ či „intelektuálni sochári“, v snahe presadit' vymyslenú predstavu o „nepretržitých a lineárnych dejinách" daného národa (či etnika), zapojili do svojich konštrukcií rôznorodé ludové povesti, rozmanité folklórne prejavy a rozprávania o starých hrdinoch, a k týmto nesúrodým príbehom pripájali poznatky archeológie, histórie a antropológie, a pod ich rukami vznikala vysnívaná narácia o tisícročných, kontinuálnych a neprerušených dejinách entity, ktorú nazvali „národ“ (Sand 2009: 14-22, 62). Sila nacionalizmu sa ukazuje v tom, že - slovami Angeli Saini - ludia odmietajú byt' „bežní“. Nacionalizmus ponúkol niektorým národom pocit, že pochádzajú z „vel'koleposti“, že ich „krv“, „genetika“ a „pôvod“ ich „obdarili“ „špeciálnymi vlastnostami“, ktoré sa predávajú z generácie na generáciu (Saini 2019: 212).

Tieto rodiace sa „národné entity“ ale neboli považované za „Frankensteinove monštrum, poskladané z orgánov z rozličných zdrojov“, ale za prastarú, „spiacu“ kolektívnu entitu („rasu“), ktorej národní intelektuáli pomáhajú precitnút', čo si nevyhnutne žiadalo vydolovat' z minulosti údajný starobylý „pôvod“ tejto kolektívnej entity (Sand 2009: 62). Postupne sa rasa začala obal'ovat širšími významami a symbolmi záväznej („pokrvnej“) minulosti či „vznešeného“ pôvodu, ktoré umožnili jednej „kolektívnej entite“, „presnejšie“ sa odlišit' od inej „kolektívnej entity“, a tým nad ňou získat prevahu (Budil 2013:10-14).

August 2020

\section{Literatúra}

Ariès, Philippe. - Duby, Georges (eds.). 1988. A History of Private Life: II. Revelations of the Medieval World. Cambridge - Massachusetts - London: The Belknap Press of Harvard University Press.

Banchi, Luciano. 1863. I fatti di Cesare. Bologna: Presso Caetano Romagnoli.

Banton, Michael. 1979. The Idea of Race and the Concept of Race. In: Verma, Gajendra K. - Bagley, Christopher (eds.): Race, Education and Identity. New York: MacMillan. https://doi.org/10.1007/978-1-34916037-2_2

Banton, Michael. 1998. Racial Theories. Cambridge: Cambridge University Press.

Banton, Michael. 2004. Race: As Classification. In: Cashmore, Ernest (ed.): Encyclopedia of Race and Ethnic Studies. London - New York: Routledge: 333-334. 
Banton, Michael. 2010. The Vertical and Horizontal Dimensions of the Word Race. Ethnicities 10, 1: 127-149.

Barnshaw, John. 2008. Race. In: Schaefer, Richard T. (ed.): Encyclopedia of Race, Ethnicity, and Society. California: SAGE Publications: 1091-1092. Bernolák, Anton. 1825. Slowár Slowenskí Češko-Latinsko-Ňemecko-Uherskí: Seu Lexicon Slavicum Bohemico-Latino-Germanico-Ungaricum. Tomus I.-V. Budae: Typis et Sumtibus Typogr. Reg. Univers. Hungaricae. Blumenbach, Johann Friedrich. 1798. Über die natürlichen Verschiedenheiten im Menschengeschlechte. Leipzig: Breitkopf und Härtel.

Braude, Benjamin. 1997. The Sons of Noah and the Construction of Ethnic and geographical Identities in the Medieval and Early Modern Periods. The William and Mary Quarterly 54, 1: 103-142.

Brézé, Jacques. 1858. Le Livre de la chasse du grand seneschal de Normandye et les ditz du bon chien Souillard qui fut au roy Louis de France, XIe de ce nom. Paris: Auguste Aubry.

Budil, Ivo T. 2005. Zrození moderní rasové teorie: Život a dílo Victora Courteta. In: Malina, Jaroslav (ed.): Panoráma biologické a sociokulturní antropologie (26). Brno: Nadace Universitas: 1-167.

Budil, Ivo T. 2013. Úsvit rasismu. Praha: Triton.

Burleigh, Michael - Wippermann, Wolfgang. 1991. The Racial State: Germany 1933-1945. Cambridge: Cambridge Univesity Press.

Conze, Werner - Sommer, Antje. 1994. Rasse. In: Brunner, Otto - Conze, Werner - Koselleck, Reinhart (eds.): Geschichtliche Grundbegriffe. Historisches Lexikon zur politisch-soziale Sprache in Deutschland, Band 5. Pro - Soz. Stuttgart: Klett-Cotta: 135-178.

Courtine-Denamy, Sylvie. 2013. Limpieza de sangre. In: Taguieff, Pierre-André (éd.): Dictionnaire historique et critique du racisme. Paris: Presses Universitaires de France - PUF: 1009-1011.

Diderot, Denis - D’Alembert, Jean. 1779. Encyclopédie, ou Dictionnaire raisonné des sciences, des arts et des métiers. Tome vinght-huitieme. $3^{\text {ème }}$ édition. Genève: Chez Jean-Léonard Pellet; A Neufchatel: Chez la Société Typographique.

Doron, Claude-Olivier. 2016. L'homme altéré. Races et dégénérescence (XVIIe-XIXe Siècles). Paris: Champ Vallon.

Doron, Claude-Olivier. 2018. Historie épistémologique et histoire politique de la race. Archives de Philosophie 3, 81: 477-499.

Dumezil, Bruno. 2015. Les ruptures dynastiques dans les royaumes barbares (V-VIIe siècles). In: Sabate, Flocel. (ed.): Ruptura i legitimació dinàstica a l'Edat Mitjana. Lleida: Pagès: 41-58.

Flutre, Louis-Fernand. 1934. Une traduction portugaise des Faits des Romains. Romania 60: 88-94. 
Fredrickson, George M. 2002. Racism: A Short History. Princeton: Princeton University Press.

Grimm, Jacob - Grimm, Wilhelm. 1893. Deutsches Wörterbuch [online]. Band: 14 VIII Wortgrenzen. Leipzig: Verlag von S. Hierzel. [2020-01-07]. Dostupné na: http://dwb.uni-trier.de/de/.

Guillaumin, Colette. 1972. Caractères spécifiques de l'idéologie raciste. Cahiers Internationaux de Sociologie 53 : 247-274.

Hannaford, Ivan. 1996. Race: The History of an Idea in the West. Baltimore - London: The John Hopkins Press.

Harper, Douglas. 2001-2020. Online Etymology Dictionary [online]. [2020-01-10]. Dostupné na: http://www.etymonline.com/.

Hiter, Walter. 1822. Etymologicon universale. Cambridge: University Press Hoquet, Thierry. 2013. Race (Biologie). In: Taguieff, Pierre-André. (éd.): Dictionnaire historique et critique du racisme. Paris: Press Universitaires de France: 1473-1479.

Castro, David C. - Fernández, Marta C. 2018. Les origines des lignages royaux et nobiliaires (Castille, XIIIe-XIVe siècle). In: Fournès, Ghislaine - Prot, Fréderic (eds.): Idées reçues et stéréotypes dans l'Espagne médiévale et moderne. Paris: Honoré Champions: 195-228.

Chiarelli, Brunetto. 1991. Razza umana: Storia e biologia. S. Domenico, Fiesole: Cultura della pace.

Isaac, Benjamin. 2006. The Invention of Racism in Classical Antiquity. Princeton - Oxford: Princeton University Press.

Jouanna, Arlette. 1975. L'idée de race en France au XVIe et au début du XVIIe siècle. Bulletin de l'Association d'étude sur l'humanisme, la réforme et la renaissance 2: 17-19.

Kamín, Tomáś - Machalová, Tatiana. 2003. Kritika rasy a rasismu. Brno: Masarykova univerzita.

Klein, Ernest. 1966. A Comprehensive Etymological Dictionary of the English Language. Volume I. Amsterdam - London - New York: Elsevier.

Králik, Lubor. 2016. Stručný etymologický slovník slovenčiny. Bratislava: VEDA.

Liberman, Anatoly. 2009. The Oxford Etymologist Looks at Race, Class and Sex (but not Gender), or, Beating a Willing Horse. OUPblog [online]. [2020-01-11]. Dostupné na: https://blog.oup.com/2009/04/race-2/.

Liddell, George. H. - Scott, Robert. 1901. A Greek-English Lexicon. Eight Edition. New York - Chicago - Cincinnati: American Book Company. Machek, Václav. 1957. Etymologický slovník jazyka českého. Praha: Československá Akademie věd.

Malina, Jaroslav a kol. 2009. Rasa. In: Antropologický slowník [online]. Brno: Ústav antropologie Př́rodovědecká fakulta MU [2020-01-11]. 
Dostupné na: https://is.muni.cz/do/1431/UAntrBiol/el/antropos/slovnik.html.

Martínez, María Elena. 2008. Genealogical Fictions: Limpieza de Sangre, Religion, and Gender in Colonial Mexico. California, Stanford: Stanford University Press.

Memmi, Albert. 1992. Rassismus. Hamburg: Europäische Verlagsanstalt. Miramon, Charles. 2008. Aux origines de la noblesse et des princes du sang. France et Angleterre au xiv ${ }^{\mathrm{e}}$ siècle. In: Lugt, Maaike - Miramon, Charles (eds.): L'hérédité entre Moyen Âge et époque moderne : perspectives historiques, études réunies. Firenze: Sismel Edizioni del Galuzzo: 157-210.

Miramon, Charles. 2013. Noble dogs, noble blood: the invention of the concept of race in the late Middle Ages. In: Eliav-Feldon, Miriam Isaac, Benjamin - Ziergler, Joseph (eds.): The Origins of Racism in the West. New York: Cambridge University Press: 200-216.

Montagu, Ashley. 1965. The Idea of Race. Lincoln, Neb.: University of Nebraska Press.

Nicot, Jean. 1606. Thresor de la langue française. The ARTFL Project. Dictionnaires d'autrefois [online]. [2020-02-09]. Dostupné na: http://atilf.atilf.fr.

Nirenberg, David. 2013. Was there race before modernity? The example of 'Jewish' blood in late medieval Spain. In: Eliav-Feldon, Miriam Isaaac, Benjamin - Ziegler, Joseph (eds.): The Origins of Racism in the West. New York: Cambridge University Press: 248-249.

Ordonnance de Roy, Concernant les Haras du Roussillon. 1751. Paris:

De L'imprimerie Royale.

Poliakov, Léon. 1996. The Aryan Myth. A History of Racist and Nationalistic Ideas in Europe. New York: Barnes \& Noble.

Rejzek, Jiř́i. 2001. Český etymologický slovník. Voznice: Leda.

Rubiés, Joan-Pau. 2017. Were Early Modern Europeans Racist? In: Morris-Reich, Amos - Rupnow, Dirk (eds.): Ideas of 'Race' in the History of the Humanities. New York: Palgrave Macmillan: 33-81.

Saini, Angela. 2019. Superior. The Return of Race Science. London: 4th Estate.

Salverda de Grave, Jean-Jacques (éd.). 1985. Enéas: roman du XIIe siècle. Tome 1, Vers 1-5998. Paris: Librairie Honoré Champion.

Sand, Shlomo. 2009. The Invention of the Jewish People. London - New York: Verso.

SP JÚL'Š SAV Slovníkový portál Jazykovedného ústavu L'. Štúra SAV. 2020 [online]. [2020-01-01]. Dostupné na: http://slovniky.juls.savba.sk. Smedley, Audrey - Smedley, Brian D. 2012. Race in North America. Boulder: Westview Press. 
Stewart, J. Devin. 1992. The disputed etymology of spanish "res". Romanische Forschungen 104: 365-379.

Stoczkowski, Wiktor. 2013. Race (Histoire). In: Taguieff, Pierre-ndréA. (éd.): Dictionnaire historique et critique du racisme. Paris: Presses Universitaires de France - PUF: 1479-1484.

Szabó, Miloslav. 2004. Boh v ofsajde. Bratislava: Kalligram.

Šafař́k, Pavel Josef. 1869. Geschichte der slawischen Sprache und Literatur nach allen Mundarten. Zweiter Abdruck. Prag: Verlag von Friedrich Tempsky.

Šafařík, Pavel Josef. 1837. Slowanské starožitnosti. Praha: Tiskem Jana Spurného.

Teysseire, Daniel. 1992. De l'usage historico-politique de race entre 1680 et 1820 et de sa transformation. Mots 33: 43-52.

Tournier, Maurice. 1992. "Race", un mot qui a perdu la raison. Mots 32: 105-107.

Vajanský, Svetozár Hurban. 1901. Kotlín [online]. [2020-01-01]. Dostupné na: https://zlatyfond.sme.sk/dielo/384/Vajansky_Kotlin-Cast-druha/7\#ixzz5oMm2Qwqt.

Valpy, Francis Edward J. 1828. An Etymological Dictionary of the Latin Dictionary. London: Printed by A. J. Valpy.

Voegelin, Eric. 1998. The History of the Race Idea. From Ray to Carus. The Collected Works of Eric Voegelin. Volume 3. Baton Rouge: Lousiana State University Press.

Vogel, Kornelis Sneyders de. 1932. La date de la composition des Faits des Romains. Neophilologus 17, 1: 213-214.

Watson, Ritchie Devon jr. 2008. Normans and Saxons. Southern Race Mythology and the Intellectual History of the American Civil War. Louisiana: Louisiana State University Press. 